\title{
Joy Victorious over Life-Vicissitudes
}

\author{
Kuang-ming Wu, Ph. D. (Yale) ${ }^{1}$ \\ ${ }^{1}$ Rosebush University Professor in Philosophy, University of Wisconsin-Oshkosh, USA. \\ Correspondence: Kuang-ming Wu, Rosebush University Professor in Philosophy, University of Wisconsin-Oshkosh, \\ USA.
}

Received: June 6, 2016

Accepted: June 22, 2016

Available online: July , 2016

doi:10.11114/ijsss.v4i9.1750

URL: http://dx.doi.org/10.11114/ijsss.v4i9.1750

\begin{abstract}
This compact essay goes as follows. First, we probe what it means to know anything at all, and such probe surprisingly shows how "to know" is already "to joy." The stage now set, we freely go from joys to more joys, joy as inter-loving caring, inter-love as joy of One Family, kids as joy invincible, to go to pain as supportive of joy, to wit, joy as so invincible as to be enabled and strengthened even by its "enemy," pain, convincingly telling of how invincible joy is. Finally "coherence" rounds up this essay.
\end{abstract}

Keywords: invincible, caring, loving, family, kids, pain

\section{Introduction}

Without exception, every one of us lives for joy to live in joy to live joy, as we all should, after all. Joy is King ubiquitous. Joy is intrinsic to life. Such joy is invincible for its two intrinsic reasons, to wit, joy cares and joy draws. First, joy is invincible because joy cares, and caring has no enemy. Therefore joy is invincible enemy-less. To put it another way, joy as caring in joy is an act of mutuality, and mutuality obliterates enmity. "No enmity" of caring joy describes how invincible joy is.

The second reason for joy being invincible is more direct. Joy by definition is a ubiquitous desideratum, for which all acts are performed, and to which all living is lived. No joy, no life. Such universal desirability of joy implicates, of course, how invincible joy is. And, to think of it, caring draws people without exception, and caring is joy at work. In short, in caring and in drawing, joy is simply invincible. These twin interrelated features constitute joy invincible.

The pages that follow would deeply impress on us with such irresistible joy invincible. These pages will mention some actual situations of our common living that are filled with joys, and elaborate on these concrete joys that draw us in. Such citing and elaborating meander spontaneously and delightfully, as life itself lives on, ever on its meandering way. This essay, compact and compressed, goes as follows.

First, we probe what it means to know anything at all, and such probe surprisingly shows how "to know" is already "to joy." The stage now having been set, we freely go from joys various to more joys various, joy as inter-loving caring, inter-love as joy of One Family, kids as joy invincible, to go to pain as supportive of joy, to wit, joy as so invincible as to be enabled and strengthened even by its "enemy" pain. Joy as supported precisely by its contrary convincingly tells us of how invincible joy is. Finally "coherence" rounds up this essay. We now proceed to elucidate how such joy goes, irresistible and invincible.

\section{Knowing as Inter-Other}

In order to know joy, we must first delve into what knowing means. Significantly, to know is to devote oneself to the other. Natural science by definition is pursuit of knowledge of Mother Nature other than science itself. Even self-knowledge is knowledge of oneself as other than oneself. In knowledge concerned with the other, brutality that destroys the other is out, as reverence is in to cherish the other. Hitler perished in brutality to destroy the other race, as Bonhoeffer also sadly perished by trying to repay Hitler's brutality with brutality, to destroy Hitler.

In contrast, Socrates' midwifery is devotion to others, as he passionately pursued universals by relentlessly asking others for universal meanings of themes that are also other than himself. Of course, his all-out quest of universals for all themes is mistaken, as many themes, such as piety, friendship, and the like, have no universal definition. But then as his early eristic dialogues clearly show, his pursuit, mistaken as it is, is itself his pursuit of knowledge of things other than 
himself, as clear as he is being himself. His showing is itself our precious knowledge of the other.

By the same token, Confucius was awestruck at those others born later than he, while he also passionately revered the past tradition other than his time, and of course those born later and past tradition are other than he. Karl Barth the great learned scholar was well-known as a greatest learner, so eager constantly to know about things other than he. And the list goes on. Our passion for knowing is our devotion to things other than we, and other-knowledge enriches our self. Other-centeredness greatly enriches the self; the other is then the target of one's self-centered pursuit. It is a surprising discovery.

It is thus that the more devoted one is to the other, the more devoted to oneself one is. This inter-enriching dialectic of self and other is centered in the other, not in the self, while obviously all of us are ourselves, not the other. Such fact is totally surprising, yet so inevitable so interesting, as well as extremely significant and ubiquitously common and ordinary. And no less significant is the fact that the other is in its turn part of our own obligation to enrich by cherishing it, revering it, and devoting to it. Now, do we begin to notice how knowing as inter-devotion already indicates knowing as inter-joy?

Whether or not the other would repay with the same coin of cherished devotion and reverence to the self, is an ever open question, which may be worthy of scrutiny as yet another peculiar "other" deserving of pursuit. This question however is perhaps impossible to pursue, simply because the other ever remains other than we ourselves, and so the other is forever impossible to know by ourselves. It is all up to the other to do whatever she wants to do. But then, wait; we catch ourselves here. Our knowledge means knowledge of the other, and so this question turns into our cul-de-sac.

It is because we are stuck somewhere. We neither can nor cannot investigate whether or not the other reveres us in return to our reverence to the other. We are cornered into a strange silence. Now, we can no longer ask if this silence is our other or not, much less whether or not this silence deserves our pursuit. Tough luck we are in, indeed! We are all cornered into a cul-de-sac. "Wow! All this sounds long-faced and serious." Well, all this is serious but not "long faced," for all this describes joy of our relentless pursuit, and so "long face" has no place in joy of pursuit.

Thus it is that, unexpectedly, our probe into what it means to know, our pursuit of knowledge of knowledge, has led us into some of the complexities of the other. In addition, to know is to be concerned with the other we want to know. This concern shows "caring for the other" that is love we desire that draws us in, as joy of caring. Knowing as caring-for-others is love in caring, to yield joy all around. This whole complex structure of knowing, care, desire, and love features joy. Joy is love in caring, a delightful mutuality, and no mutuality has enemy. In all, joy is invincible all around.

Socrates in Plato's dialogue of Symposium explains knowing as sexual union between Eros the desire, due to its lack, and the desired object of knowledge. Socrates does not look into what the child sired by such union is, but we know it is obviously joy. Still, we daunt at taking desire as a lack. For us, desire is rich love immersed in joy, drawn by joy to yield joy. Joy overflows as both cause and result of caring love of the other. This complex interrelation that composes joy is now to be exhibited in the pages below, to draw us in with our desire for joy, as no one can resist such joy all invincible.

\section{Joy as Inter-Love to Inter-Care}

Is all the above description on knowledge as joy accidental or necessary to our living? However we answer it, "accidental" is joy, "necessary" is joy, and wandering unsure between the two is also joy. Why is joy crucial? It is because we live for joy to live joy. Without joy we cannot live. Living is serious, and so living is seriously joyous. Are you in pain? Living in pain proves that you are living, and living is for joy to live in joy. Your obligation to yourself now is to manage to turn pain into joy. That is how you go and see the doctor.

In addition, we notice that, in joy, fact and obligation join. Joy is the fact of life, and so we are obligated to live joy. Joy is our fact of life, and living is both fact and imperative. We must live on as we actually live on. By the same token, we often do actually live joy, and if not, we must manage to live in joy. Joy is our actual fact and our categorical imperative, both at once.

Let me repeat this important point. Whenever we lack joy, as we tend to in our daily struggles, we must live joy, because "lacking in joy" itself shows we are alive, and being alive involves life as for joy to live in joy, and so the very fact that we are living — our pain tells of our living, for no dead person feels pain —obligates us to manage to live in joy on and on. Let us emphasize this point. Living is (to be) joy no matter what, and so we alive must live joy no matter what.

Joy is such a categorical imperative absolutely unconditional, as living on is our life-imperative absolute and unconditional, because all of us must live on - and this "must" of living is the existential imperative. If we must live on, then we must live to enjoy life, and this latter "must" is an imperative that is both existential and ethical-moral. All this amounts to saying that joy is as serious an imperative as joy is never long-faced. "Long faced joy" is an oxymoron that 
can never obtain, as long as we live on, in fact such oxymoron can never exist anywhere anytime.

In addition, here is an important fact. Joy can never be resisted. "Rejection of joy" is as much an oxymoron as-in fact, more than- "long faced joy." Joy is stronger than death and more ferocious than hell (Pope, 1995), because it can never be resisted, not even by devil, for even the devil has no choice but to use joy to lure us. The Song of Songs 8:6 features love as such. Its irresistible phrase is rifled here to feature joy. After all, love and joy involves each other. It is thus that joy is the imperative both absolute (as life is absolutely binding on us) and invincible (as joy can never be resisted).

Joy is thus all smiles, never long-faced. In joy, every one of us is a winner laughing together, ever. It is because absolutely no one can lose in joy. Joy is the unique command all serious, invincible, and all-powerful that is constantly imposed on us to always enrich us. Joy is so powerful as to be able even to resuscitate us as we say die, giving up on everything we have been hanging on to. We simply must manage, no mater what, to live joy so absolute so serious, and so enjoyable. Being enjoyable is the very power of joy that commands and induces us on.

And such inter-joy even between living and disasters indicates inter-love no matter what. Concrete examples abound on joy as love and love as joy, no matter what. Here are two examples. The first one is this. As I was walking, I met a tiny boy sobbing on the shoulder of tall Dad. I said, "Don’t cry, honey. You cry, I will cry, too, OK?" "Dank, Gumpa," said the boy, and calmed down. In all smiles, Dad walked away, still hugging him. Left behind, I was in tears-of that boy. That's deep joy in love, isn't it?

And then, I was huffing and puffing up the up-going road. A lady drove over to me, and then drove me up the school compound. And then, she walked me hand over hand up the stone stair-steps, saying all this while that she could shoulder me upstairs if I want her to. I saw in her car a picture of Kuan-yin Bodhisattva. That's joy in love caring, isn't it? Those two scenes in Taiwan are carved deep into my soul. Such caring is joy completely irresistible, as it is so invincible. Life is made of such joys, isn't it? What else is life for?

Here, I see Kuan-yin caring embracing Jesus, as they shake hands facing each other. Confucius in pan-reverence is smiling with them both. In inter-reverence they join hands caring in joy for people in pain, each in her/his own ways. Debates over uniqueness of each, polytheism, pantheism, or even mysticism, are far away from them all too busy caring to bother with such debates. Care-pragmatism rules their day, of all joy together. Such is heaven on earth, again in total joys.

Now, have you noticed how the Heaven the realm of extreme joys is composed by care-pragmatics? In heaven that spreads down to earth all over, caring is joy together, inter-caring in inter-joy to inter-compose, as every entity in the world continues inter-implying and inter-elucidating. Seeing the one reveals the other. Such inter-revelation is due to the fact that both caring-for-all and joy-of-all express the most intense interactions among all beings to inter-enrich to inter-win.

Everyone is the winner in inter-caring, and winning is sheer joy, of course. All this amounts to saying that the Heaven is the victorious realm of extreme joys. And isn't the Heaven what all religions are about, each with its own interpretations of it? Religion is Joy Supreme in Caring Supreme, both at the summit of interactions of all things to inter-enrich. Religion is Heaven on earth; religion is nothing but incarnation of the "inter," all supreme. Religion is the "inter" supreme, as Heaven on earth.

Now we have just completed explicating what Heaven and religion are, to wit, Heaven and religion as Joys Supreme as the "Inter" Supreme. This "what" implicates at once our categorical "must"-imperative. Actuality of existing facts implies obligation still to be actualized in full in joy. We actually existing simply can never evade this supreme obligation and responsibility to practice joy in caring, to provoke producing caring for one another all around into inter-joy of all in all.

In this Heaven on earth seeing "you" is sheer joy of seeing you caring for me, as I serve as "you" to you to help you out into joy from pain, by supplying resources for power to stamp out pain of whatever sort. Such inter-caring is the source of natural and vital joy indefatigable and irrefutable, and so, caring all around in joy is totally invincible. All this loving joy composes "Heaven" that is the network of inter-caring in inter-joy spreading all over, as it is inter-strengthened on and on.

This spiral of inter-strengthening, repetitively performed as the repeats of its description above, has no limit, as its limit is the sky that is Heaven, religion supreme, and caring supreme in joy supreme. All such supremacies have no limit. Limitlessness and supremacies inter-imply to inter-compose, because they have their shared content of inter-joys in inter-caring, all continuous unlimited, and that is why all this is an elucidation of what the limitless Heaven is and what religion supreme is. I am fully aware that all this explication goes round and round, as going around inter-elucidate. 


\subsection{Inter-Love as Joy of One Family}

My god, I have kept going, for I have got carried away, simply because I cannot help being carried away. Joy that I cannot resist has made me do it. I look around and notice "mother and child" right here. Mom and her kid cannot stop prattling on and on about their joys together in their caring for each other. Their caring is their joy. They simply cannot help it, for how can anyone resist joy, which is composed of caring?

Unbelievable as it may sound, all beings that there are exist together as my body that is only one of them. This is because my body begins all existents so immensely many. To begin with, my body tells us that my eyes cannot walk without my legs, and my legs cannot even walk without my eyes seeing how to walk and whereto. My teeth bite into things outside, chewing them into my food to keep me alive, and my teeth turned senile must be cared for to protect me against lowered immunity to court death by catching pneumonia. Meanwhile, hiccups up here call and answered by farts down there.

In such ways as these, all of us so many so various are equally needed to live on, as they are all equally and utterly in need of one another to function together to live on, by being mutually supportive and complementing, so much so that we together constitute ourselves as one body communal. St. Paul devoted a concrete substantial chapter to meticulously describing how one body we are, in order to lead us into its comprehensive "secret" of "love" that accepts us all without complaints so many, in the next chapter (Zodhiates, 1998) .

Paul did not mention the ultimate summit of such love, but we know what it is. It is joy comprehensive and invincible. My joy constantly turns into our body-joys of all beings various yet one body communal. Merely to exist is sacred, because merely existing is sheer body-joy in the one holy family ubiquitous. Our shared ideal of "One Family under Heaven" is actually tangible and viable as "my body" on which each of us lives. We routinely care for "my body"; we assiduously and interactively practice the building up of this common ideal of One Family "my body" on which we all depend to thrive, on and on.

Again we always notice. The baby is the body of his Mom on whom he lives, staring at whom Mom is thrilled with joy ineffable. Her baby is her body her life. No wonder, Mom cares for her baby 24 hours a day 7 days a week, as Mom routinely cares for her own body. Caring for her baby her body is her body-joy on which she lives. In the exactly identical manner, only in a much bigger and ubiquitous scale, our "One Family" we live on is as close as "my body" we take care of.

Our One Family is so much in need of our caring to nurture, for that Family is our baby our body we daily care for, without whom we are nowhere. Our Family is our baby-body, for whom we are shouldered with constant caring responsibilities. Without engaging in these responsibilities we are simply nowhere. Our Family is our mundane, routine, and intimate body-responsibility to raise and keep, and as global ubiquitous a joy, as "my body" for which each of us cares to live on.

In such caring way as this, and in this joy-way, Heaven and earth compose One Family totally personal private and totally public ubiquitous. Such One Family describes religion supreme in Heaven limitless. Each religion would agree and join in with this Family; in fact all religions cannot help but agree and join in from their respective points of view and for their respectively peculiar reasons. In their shared ideal of One Family, their distinctness of perspective and reason establishes their respective uniqueness each in its own way.

All this while, their total agreement to sheer inter-joys together makes them into One Family precisely through their distinctness. Their total unity gathers them up into Heaven totally open. Heaven is all-open to anyone who cares to ascend, and ascend all of us must, by simply being drawn into joy supreme up there in Heaven. Such heavenly supremacy is ubiquity by its sheer drawing power of joy in Heaven that cares. Heaven totally open is constantly in total caring in total joys.

Ho! Everyone! Buy joy priceless with free money of yours that is your own desire to live on and on in joy! Desire buys, joy draws, and every single person is so very happy together, being cared for to turn into a proud winner! All orphans now have parents, and all childless parents now hug their beloved children, as all siblings help and serve one another. This entire situation describes One Family under Heaven throughout Heaven, all irresistibly happy, being so happy together constantly caring one for another, irrespective of how poor and ugly "you" are, how different smelly "you" are from me.

One Family in this way sings various odes antiphonal to joys of all music of all spheres up and down, world without end. "Without end" describes sheer joys of caring one for another, inter-enjoying inter-living, on and on. O, I must stop now, because I cannot stop it, being in so much joy together, as everyone, literally each one, is the winner unique and personal. Joy is unique and ubiquitous, because joy is caring that is both specific and spreading on and on, in Heaven as it is on earth. "In Heaven as it is on earth" signifies ubiquity of joys together, world without end. 
Let me put all this in this way quite personal. As the river of time meanders on, kids grow up, and now would not take a second look at their young "toy box." But this box remains the unique treasure trove for their Mom, with tons of tender stuff in it, all eternally precious, as "grownup kids" remain Mom's kids. "Your trash is my treasure, dears," Mom mumbles in tears, hugging kid-broken toys strewn in the box. Motherly concrete thinking must look into life's treasure-trove of its "toy box." Now, we all are award of concrete examples to concretize all this.

Concrete themes concretely elucidated concretize their elucidations; it is concrete thinking incarnate. Joy, music and other suchlike are life's typical themes that no one in the West or in China has noticed, much less probed in enthusiasm. We enlist combination of the West's logical analysis and China's bodily discerned story-insights to bring out their life-significance, as we cannot live without joy as we have no culture without music. Let us just take joy as an example. Simple joy is not a simple open-and-shut case.

Joy requires Western logical analysis to bring out its hedonistic paradox, and its Chinese concrete clothing in story thinking to bring about bodily-logical resolution of the paradox. We need both the West's discovery of joy-dilemma in logical analysis, and China's body thinking story-thought concretely, to plumb and develop joy in life-thought depth. Elucidating joy this way is itself joy; it is concrete thinking concretized. All in all, joy is completely invincible.

The hedonistic paradox discovered the well-known thinker Sidgwick (1974) goes this way, to wit, the more pursued, the far away happiness recedes. We all desire happiness and try to pursue it, but happiness just happens, never to be pursued without vanishing. For all that, however, we simply cannot help but pursue what we desire, our happiness, and we are impaled in our counterproductive pursuit. We can neither pursue happiness nor stop pursuing it. We are cornered into a cul-de-sac both logical and existential.

Incredibly, China innocently revels in this paradox; it pursues happiness without pursuing it to freely obtain it. How does China do it? It gets happiness by following the life-situation as it happens. And China would happen to get happiness that happens to happen. A concrete example shows it; that example happens to be motherly caring. Tommy was so happy playing and shouting when Mom called all of a sudden, "It's time for nap, Tommy." Wow, how incensing that call was! Tommy yells, "No! No! No nap!" "Nap" is his nasty three-lettered word untouchable, for the world is too exciting to miss by such silly nap!

But still, his angry shouting shows how tired Tommy is, in an absolute need of nap. Now, Mom faces a dilemma. Tommy refuses nap his fatigue can never dispense with. What can Mom do? Mom loves Tommy too much to simply let him go, for he would at once stumble into a terrible hurt. And yet Mom cannot just push him into bed, commanding him to sleep, either, for it would start WWIII mess. Mom is caught in a hedonistic paradox; she can neither pursue nor not pursue Tommy's happiness.

In her spontaneous caring love, Mom then says, "OK, Tommy! No nap for you. Just come over here and sit on your bed, for Mom will read you your favorite story. But no nap, OK?" Now how could Tommy turn down such delicious offer? He nods, and comes and sits on his bed. "Once upon a time, there was a bad old lady call "Miss Tiger Lady." Whereupon, Tommy hits his pillow. Mom tucks him in, and softly tiptoed out. The hedonistic paradox is happily resolved in happiness, by following along in care.

Caring is joy because of its twofold life-situation so irresistible, as follows. To begin with, when one cares for something or someone, that treasure is cherished more dearly than oneself at one's best. One unceasingly hugs and strokes what one cherishes, as one keeps staring at one's treasure, completely unable to turn away one's gaze, all-enthralled. Being in the presence of one's dearly beloved is being in heavenly bliss of an utmost joy ineffable.

Caring as joy is poignantly borne out by its contrary, missing someone. Missing my dearly beloved, I soon suffered psychosomatically a stomachache writhing for over three hours at night, and then three vomits quite painful, followed by two diarrheas aplenty. After such pain stopped, for three days I still remained totally exhausted, crawling into bed lying flat, quite often.

In this way, missing someone dear misses my dear self that is my whole life. To miss my beloved is to ache after her in existence in no-existence. I keep aching at her ab-sence, her no-presence while she is present so dear. It is because, all this while, she is clearly present in me yet as clearly absent in me. Her absence makes me ache after her absent presence. This existential contradiction precisely composes the pain of missing someone beloved. Does this situation parallel the dilemma of hedonistic paradox?

Such sheer pain of "missing" someone beloved and dearly cherished is tragically typified by the baby crying after his Mom who is his very life. The baby crying after his Mom his life is no pesky joke, never to be taken lightly and casually. The baby is always the parent to adults, typifying our shared basic humanity. No wonder, Poet Wordsworth (2009) feelingly chants, "The Child is father of the Man." In this way, missing the beloved cherished shows how joy is a mutuality of love in need in satisfaction of inter-caring. 
By the same token, to apologize and to be forgiven and accepted is such joy. Such joy can never be measured in quantity, much less evaluated in terms of dollars gained. The network of apology and forgiveness is sheer joy inestimable all over all around, and no one can take away such joy so full to overflowing and overwhelming. Everyone would smile at apologizer and forgiver-acceptor, even though it is none of the business of bystanders, except for apologizer and forgiver-acceptor.

An exactly identical situation of joy happens in giving thanks and receiving them. To thank for something to someone is also sheer joy inestimable, as well to receive gratitude, in all smiles. Joy also happens as one cares for something and someone dearly heartfelt. One simply has to tend the wellbeing of one's cherished treasure, and this "has to" happens in joy irrepressible. All such joys are specific personal, and spread all over as "joy" without exception as "joy" among persons in joy and watchers on the side.

Dragging the tattered blanket of her life, that dear infant keeps hugging and kissing her treasure, mumbling her concocted chants of love. Such is how she takes care of her treasure her blanket. Have you seen a young missy in her utmost worries, putting forth her faded "Barbie" that is herself to her trusted doctor? That doctor, in turn, fully concerned, puts his professional stethoscope onto that doll's heart with complete seriousness. Rockwell (2002) sensitively captured that scene, and that expert-painting is hanging on the wall of my doctor's office.

How many practicing doctors have enough caring sense to cure a doll to heal their beloved patients, no matter how young they are, and no matter how irrational they seem? If these people are troubled, they are really sickened. They are sick enough to see their trusted doctors, who must then cherish their concerns to seriously engage healing them with all their trained professional expertise.

Here is another concrete example. As my Dad's first baby, ten month old then, I suffered from erysipelas writhing in pain. I hugged on to Dad with my whole life, just wailing, "Dad! Dad!” Dad in response vowed to pair his total life with mine, and devoted so many nights and days without a stop to concocting curing drugs after curing prescriptions, as he was a professional pharmacist. Finally, he had to appeal to blood serum for cure. It finally worked, and no one can imagine how happy Dad was hugging his numbed baby in his arms!

After the cure, my skin turned so sensitive as to break out in big bloats of liquid at the slightest bite by mosquito. Each time, Dad carefully drained out the liquid and bound the wounds with layers of gauze bands. Such care lasted for years until I was big enough to run around. Dad intensively listens to whatever silly stuff I said, as I was just ten or eleven, as if I were his devoted adult friend. That is caring in joy that does not giggle at all. Such is joy forever caring for kids, absolutely invincible.

\section{Kids as Joy Invincible}

Such are the life of Alice's in Wonderland with all Tommy's running so naughty. They play with reasoning, reasonable or no, shouting at one another, "You are no-K! We are OK!" In their delightful shouting in stark depths of authenticity is their simple profundity of living reasoning, all irresistible. Of course we must protect them from hurting themselves and others, but nothing is more important than enjoying living, and the messy kids lead us all adults the way to it! Fun is reasoning supreme! What else but fun do we live for? Even that silly long po-faced Aristotle (Aristotle \& Irwin, 1999) had to declare what all men agree, that "the highest good attainable" is "happiness."

Children are powerful fourfold way: stark, romping, at play, and in joy. First, kids are stark in their sheer presence. They like what they like and do not like what they do not, no cheat, and no duplicity. Second, as kids do not walk but prance, run, and romp, the whole world rocks as the whole neighborhood is served notice to hear them. Third, their powerful authenticity is forever at play, quite serious, and at the same time play is absolutely free, totally carefree.

Finally, such stark romping play is sheer kid-joy all-contagious. Even Granny laughs, forgetting to knit scarves and sweaters for kids who don't want them (yet need them). The world is ablaze with noisy kids so messy. Reasoning is smashed into pieces, and then each piece arises kid-alive as new coherent reasoning all its own. Kids are here shouting, messy and mesmerizing, in new reasoning in kid-vigor. Kids are the phoenix of reasoning quite deathless quite irresistible. Kids incarnate our very goal of life as joy. All in all, joy is completely invincible, as shown by messy kids.

In addition, importantly, we must keep firmly in mind a crucial point that peculiarly belongs to kids. It is that kids are forever relaxed, and that is why kids are forever full of joy-pep. Pep and relaxation belong together to constitute joy invincible that is fully kid. Kids are joy as peppy relaxed. Joy has no room for anything jittery, upset, uptight, or pushy. Joy is ever roomy, at home in itself. Joy is relaxed. Joy never pushes. Joy is ever roomy, relaxed — as kids are.

Kids sleep long and often, and so they can afford to be relaxed in any situation, as they run around shouting wailing all day and not turning hoarse. All this can happen to kids, for kids are masters of relaxation. The result is that they are always full of energy and absolutely active, even while they are just standing. Kids are the eternal envy of all of us because they are eternally peppy, and they are always active because they are always relaxed, in shouting fighting as 
well as in sleeping. As kids shout and run around, they are ever ready to drop into Mom's lap and turn completely unaware.

And then, now totally relaxed and recharged, they jump up "any time" to run again, shout again, and fight again, all totally relaxed well-slept. Kids are all-power all-alive in all-joy, because they are always relaxed at any time at all, even while fighting. Pep, joy, and relaxing, these three together imply one another and compose each other, to constitute kids who are our eternal envy.

Now, of course, kids are spontaneous and simple, and so they are simply relaxed. Their relaxation explains how kids are ever our target of envy, for we are sadly no longer spontaneous and simple. We have been trained into targeting some goal beyond us "over there," toward which we are now used to try to strive after, trying to go beyond us here now. But kids are our target of envy because of their relaxation, and so we try to strive after relaxation that is the secret of kids being attractive to us, and- $\mathrm{O}$, such tragedy! - trying after relaxation disperse relaxation.

The harder we try to relax, the less relaxed we turn; the more we chase after relaxation, the less relaxed we are. Striving after relaxation-as-target chases away relaxation. We in adulthood are interminably condemned to a counterproductive quicksand and cul-de-sac. Is all this another version of the hedonistic paradox? Adulthood is forever jittery anti-relaxation, and relaxation is what originates the primal kid-power, raw, primitive, and rugged invincible. "But we are adults. Can we adults get out of our nasty adulthood?" Incredible as it seems, we see two tactics out of adulthood.

The first adult tactic that can be proposed is this. It is to back off a step, and there opens out ocean wide, sky vast, all relaxed. An explanation is in order. To begin with, backing off a step does perform an act of backing-off, and performing is a striving we as adults are accustomed to doing. We adults can, as adult, freely try to back off as we are wont to try.

And then, secondly, as our act of back off from being uptight will automatically destroy being jittery and upset and uptight, and relaxation appears all by itself; we now turn relaxed unawares, without even trying. Relaxation is neither doing nor not-doing, but a no-doing, a wu-wei 無為, as China would say. Are Mom and Tommy here? Relaxation is an unintended by-product of our trial at backing off, a casual unexpected serendipity beside our intended performance. Is the hedonistic paradox resolved here?

And unexpectedness is spontaneity that is the essence of relaxation unawares. Such spontaneous relaxation will appear all by itself without us consciously trying at it - spontaneity cannot be tried after-while we try at something else than relaxation, trying at backing off from trying. We strive to give up on striving, and striving is given up and vanishes into spontaneity that guides us into relaxation. Thus, the first adult tactic into childhood is to back off from adulthood-into relaxation as the kid lives.

One more adult tactic we can have, out of adulthood into childhood, is simply to play with shouting messy kids, who would simply accept us as their clumsy playmates; after all, play enjoys playmates, and the clumsier ones they can have the better it is for them. Nothing is better than an expert player, who is actually a clumsy player, they would claim! In such way as this, playing with messy kids will delightfully allow kids to guide us adults into forgetting our jittery uptight selves, and self-forgetting is a royal road to - if not the essence of-relaxation.

All this relaxation can spontaneously take place because self-forgetting leaves self-conscious reflection on oneself, and thereby leaves the uptight self trying to capture itself self-consciously, to worsen self-consciousness so jittery. Leaving one's self, all too self-aware so jittery uptight, relaxes oneself unawares. One's self thus turns spontaneously oneself. And "oneself at home in oneself" spells relaxation.

"Leaving oneself leads oneself to be at home in oneself? Are you serious? Are you joking?" Well, sorry about munching on a seeming paradox, but this paradox of spontaneity parallels the hedonistic paradox to resolve that paradox, my dear friend. I came to have learned this precious lesson by playing with kids, who taught me without trying to teach me at all.

Kids would spontaneously guide us into such forgetting of the self, as kids are experts at forgetting everything, including themselves! Kids self-forgotten are kids ever relaxed. All kids all-relaxed guide us relaxed. And the kids guide us by simply accepting us as their clumsy playmates and playing with us, all quite spontaneously, without even aware, for they are not even trying to accept us and play with us. We now shout as kids with kids, as we fight with kids as kids, and we automatically leave our uptight adulthood into relaxation so natural as kids with kids so spontaneous. It is in such way as this that kids guide us into relaxed joy all invincible, as they are.

\section{Pain the Reverse of Joy as Deepened Joy}

Now, let us go to the other extreme, pain, to under-gird joy from its opposite end. Rejoice with me, my dear friends! I have just survived, though still helplessly tired, two teeth extracted, a severe protracted stomachache, followed by three painful vomits, and two big tiring diarrheas. I am now resting my inside belly, still feeling hollow and feeble. I sleep 
often, acting out much less often, drinking much water, $1000 \mathrm{cc}$ at dawn, another $1000 \mathrm{cc}$ at dusk. I am still surviving but my bottom has fallen off, and I am all fallen apart into bits and pieces.

All this while, my whole body is repairing itself, silently and slowly, as I do feel it. I continue to rise out of bed as usual, as the sun rises at dawn, shy but sure. I cannot thank enough the Beyond behind me and below me and beyond me, entirely surrounding me. "But why do you not complain instead about your sudden pain, coming over you without rhyme or reason? Why do you not ask the Beyond for change of this course of events?" A sensible objection you raised, my friend. Well, I do not ask the Beyond for change for two reasons, both quite significant.

My reason-one is this. Such a request amounts to asking to change the course of common events, and such event-change is to change the whole frame of the world. "Well, we would just ask the Beyond to give Hitler, for instance, a tiny headache to change his mind about the Auschwitz oven." Yes, you want the Beyond to change here a bit, and soon you would wish the Beyond to change a little there also, and sooner than later the whole world would turn monstrously misshaped.

The point here is that we are never divine, and so we never have an overall flow-chart of the ongoing of the universe. We can mumble about "the best of all possible worlds" as much as we want, and forever remain totally ignorant of what this wonderful phrase has in it. This phrase remains for us all-empty, and we are forever totally unable to request any sensible, reasonable, and meaningful change, however slight, on the course of events as it goes on as usual.

After all, to err is human, and to humanly err on the serious framework of the whole world is disastrously serious indeed. Such is why, being human, I reasonably refrain from asking the Beyond for any change in my pain-undergoing. This is my reason-one for not asking the Beyond to take away my pain, however unbearable. Being human I simply have no right, much less ability, to do so, for, to repeat, I am personally never divine, ever remaining human subject to errors so often.

In addition, importantly, miracles for the good do happen through the very usual course of events, even if they happen not as often as we wish, and in fact, do happen more than we realize, for they often happen without our knowing about them. We think of such a wonderful miracle through natural course of events, such as Baby Moses-Moses means "pulled out" - pulled out of drowning by his gutsy baby-cries heard by his archenemy Pharaoh's daughter, and then given back to his mother to raise him with pay. And so, we can never complain about all usual courses of events, for some common events do happen for good, even without our being aware of them.

My reason-two for not asking the Beyond to take away my pain that I resent, is more personal and perhaps stronger for me. It is stronger and more elating to ride over the crest of waves of pain, and come out victorious through all such thick and thin, than simply to be relieved of pain, and turn into a spoiled, feeble, and whining weakling. Being relieved of my pesky pain when it comes on me, this time, will result in requiring a relief of less tough pain but as unbearable as the one before, and I will end up turning rotten spoilt as a bottomless and impossible weakling unfit to live at all.

Instead of such easy relief of pain described here, it is best for me to face up to whatever comes on, usually unknown to me, to tough it out. And then, I will turn tougher and better prepared for the next oncoming of unpleasant pain, including perhaps an even tougher one yet. I am now a worldly person worldly strong, worldly weathered, and worldly wise, all prudent, all careful, and more resourceful than ever before. As my mistakes that I resent creates unexpectedly things novel in which I am pleased, so whatever that comes on to me that I resent, toughens me up into a tough authentic person among all usual persons.

And so, all in all, please rejoice with me, my dear friends, for surviving these unexpected ordeals, all so tiring and painful. O, I am so very happy indeed, after undergoing all such pain. Of course, I am still far away indeed behind Confucius who has been so totally happy as to forget meals and forget the old about to arrive on him, while he has been in constant failures throughout life!

But still, however far behind Confucius as I am, I am following him, in my joy in all my pain. I am tougher now in my entire feeble hollow, and even my hollow is all-joyous all peaceful. I am taking it easy, carefully, as if treading the thin ice so slippery. All this is so chilly so risky. Now it sounds incredible, but precisely within such chilly risks, I am in joy all over. Such happiness in risky pain tells of my joy tougher than pain however deadly, however pesky, and however unbearable.

I am continuing to be on my way through my entire pain in all risks. Here I come! So help me, my Beyond, who is ever staying with me. Again, let me stress this fact. In such way as this going through, even pain strengthens and deepens joy all around. All in all, joy is all invincible, precisely during the undergoing of pain often deadly unbearable. Joy is stronger than death! Joy is more ferocious than hell, thanks to joy being all-careful in caring for all persons, each in her own need her own pain to come out a winner uniquely her way. 


\section{Joy Invincible as Coherent}

Now we must-it is an existential "must" - delightfully round up all the above pages that delightfully meandered all around on "joy." We must do so in joy by asking what being "invincible" means. And we suddenly notice that, as delight is synonymous with joy, so "must," "round up," "meandering," "asking," "meaning," and even "invincible," are all so intimately connected as to constitute One fully close-knit Family, both in space as a family and in time as meandering as coherent.

In fact, being invincible is to be all-comprehensive and all-coherent. Coherence is the name of this One Family described above, ubiquitous and joy-filled. And so, to avoid meandering out too far, "coherence" as such is probed now. "What is coherence?" As things are "con-cresced grown-together," nothing concrete is scattered in random bits and pieces; instead, everything existent is "coherent" ("coherent," 2008, 2001) stuck-together as itself and no other.

And thinking that mirrors concrete actuality so coherent is by its nature coherent as well, not arbitrary, haphazard, or hit and run accidental without rhyme or rhythm, but stuck-together coherent into a systematic web (Wu, 2010, 2012). As concrete things are stuck-together, concrete thinking is not scattered but stuck-together coherent, to exactly mirror concrete things stuck-together coherent.

At the same time, surprisingly, both the concrete and its thinking are the spontaneous free birds flying over anywhere sky-high, devil may care. Concrete thinking can never be trapped in a "pre-established universal harmony," whatever it may mean. Concrete thinking is fully systematic in actuality and yet never a set and settled system. Concrete thinking is ever systematic with no system, ever making web with no weaver as Chinese medicine advertised is (Kaptchuk, 1983). Chinese medicine celebrates healthy body-thinking.

"What are the differences between coherence and system?" An interesting question you raised, my friend. "Coherence" is a verb-word connoting continuous initiation of cohering phenomena. "System" is a noun-word implying the nisus toward the result. Logical analysis in the West is concerned with a system. Concrete thinking and story thinking are cohering activities all open. Body thinking and music-thinking describe systematic goings-on as they ever initiate producing new systems yet to come about. All these modes of thinking as typified in China have an "-ing" form that implies cohering activities ever on the go.

"What is music thinking?" Our whole body vibrates and sings. Our hearts and lungs rhyme with the rhythm of body-life music, and the whole brain is involved in music as every cell throbs singing. All this body-music is body-meaning more basic than usual meaning to generate usual meanings. And just listen to Kempff playing Schubert, and we will realize how music sings meaning behind meaning, and so sentences that sing — as sentences in China always do — sing the original meaning behind all meanings that are systematically and explicitly expressed. Music thinking lurks behind concrete thinking body-expressed and story-told in open coherence, ever on the go.

Story thinking is constantly turning coherent all events as they happen - no matter what, how, or even why - to make sense of them. And such is precisely what music does, turning any dissonance into harmonious and sensible music of the spheres down here and up there. Music thinking is thus the basic, original, and originating thinking that under-girds concrete thinking, body-existential, story-told, ever.

All this while, natural spontaneity meanders, and such meandering is coherence alive in Mother Nature. Coherence is togetherness that is sensible; coherence is the concrete logic of togetherness (Wu, 1998), as inevitable as it is invincible. To begin with, coherence is inevitable because without coherence any entity whatever would break apart into scattered bits and pieces, to vanish in mist. And so, in fact, even each of these pieces must be coherent-as-itself to appear as "a piece." And this "must" must obtain everywhere for anything at all to exist, even as a piece. And so, the being-togetherness is comprehensive, and being existential comprehensive amounts to being invincible.

Still, being invincibly comprehensive cannot be tied up into "a system." Invincibility all concrete meanders as one networked river of all existents, and such being-meandering is meaningful as coherence-in-time. Coherence in time is alive, penetrating all to pervade all, and "all" here indicates joy as existence is coherent and to exist is itself joy, and joy here existential is invincible because joy is existent all over, and such joy all over can never have its contrary its "enemy," and "no enemy" is invincible.

In addition, we must remember. Such comprehensive joy of togetherness and coherence can never be general in whatever sense. The joy of invincible coherence is incurably specific and unique at each moment. Such unique specificity meanders spontaneously in time to exhibit natural coherence totally incorrigible. Joy can never be "general joy," a contradiction existing nowhere. Joy is for ever my joy, your joy, and so on, always an individual joy, each different from all others.

And we must take note. The phrase itself, "all others," expresses specificity all over, and such universal specificity is never "general" but only specific. "But 'universal specificity' is a contradiction," you protest. I agree. It is indeed a 
contradiction when seen as a spatial connection. But we usually forget time-sequence. "Universal specificity" is a natural expression of coherence in time meandering. Such coherence-in-time is naturally specific and universal, and this universal specificity in time is naturally presented in all the pages above.

Furthermore, mind you, this natural joy coherent exudes—all too spontaneously—no less than joy totally inexpressible and inevitable, and so invincible all around. Natural meandering is "joy invincible." All the above pages are themselves "joy invincible," irresistibly drawing into it each and every one of us in contact. "Each in contact" produces joy coherent all over, and joy all over is again joy invincible. Joy is everywhere at any moment, so much so that we are always so happy, so much in joy that we do not know what to do with ourselves, in joy or in pain, in failure as in success.

We can now understand, however distantly and vaguely, how totally delighted Confucius was, so much as to even forget meals and forget the old about to encroach on him. He continues being "forever 21 " precisely in the midst of failures continuous throughout his life. Confucius is joy invincible incarnate, specifically himself yet looked up to by all of us worldwide. This Confucius in joy invincible is alive today to accompany us through all thick and thin, to guide us into our own joy invincible. Nothing more can be said. It must be done and lived delightfully, with kids invincible and with Confucius forever 21.

\section{References}

Aristotle, \& Irwin, T. (1999). Nicomachean Ethics (2nd Ed.). Indianapolis, IN: Hackett Publishing Company.

Coherence. (2001). In Oxford English online dictionary (2nd ed.). Retrieved from http://dictionary.oed.com

Coherent. (2008). In Merriam-Webster's Collegiate Dictionary, Eleventh Edition. http://www.merriam-webster.com/

Kaptchuk, T. J. (1983). The Web That Has No Weaver: Understanding Chinese Medicine. Chicago: Congdon \& Weed.

Pope, M. H. (1995). Song of Songs. New York: The Anchor Bible.

Rockwell, N. (2002). Norman Rockwell. North Dighton, MA: J G Press.

Sidgwick, H. (1974). The Methods of Ethics. Chicago: The University of Chicago Press.

Wordsworth, W. (2009). The Complete Poetical Works of William Wordsworth. Boston: Houghton Mifflin.

Wu, K.-M. (1998). On the "Logic" of Togetherness: A Cultural Hermeneutic. Leiden: Brill.

Wu, K.-M. (2010). Chinese Wisdom Alive: Vignettes of Life-Thinking. New York: Nova Science.

Wu, K.-M. (2010). Nonsense: Cultural Mediations on thee Beyond. New York: Nova Science.

Zodhiates, S. (1998). Anointed, Filled and Gifted: First Corinthians Chapter Twelve Exegetical Commentary Series. TN: Chattanooga.

\section{(cc) EY}

This work is licensed under a Creative Commons Attribution 3.0 License. 